\title{
ALIH FUNGSI LAHAN PERTANIAN KE PERUMAHAN DAN DAMPAK KESEJAHTERAAN EKONOMI PETANI DALAM PERSPEKTIF EKONOMI ISLAM
}

\author{
Mabruri Faozi dan Nur Ihsan Syariffudin \\ Fakultas Syari'ah dan Ekonomi Islam \\ Institut Agama Islam Negeri Syekh Nurjati Cirebon \\ email: mabrurifaozi@gmail.com dan ihsan_nur@yahoo.com
}

\begin{abstract}
Land conversion is a change of land use into a new land use that is different from the begining, in this context is the change of agricultural land to housing. Land nonproductive cheap and positioned to make housing in the area Sumber District Cirebon is very little compared with the productive land or to specify an agricultural land, because in the area of the District Resource own the majority of agricultural land is more dominant, not inevitable agricultural land being targeted by investors. Agricultural land they consider strategic for their housing built to turn into housing. The armers who have land must think hard how they rotate their economies after their land is sold. This is where the well-being of farmers who had direct agricultural land and agricultural land tillers who became the focal point. The method used here is qualitative by using a system of observation, interviews and documentation.
\end{abstract}

Keywords: Islamic Economic, Land Conversion and The Welfare of Farmers.

\begin{abstract}
Abstrak
Alih fungsi lahan adalah perubahan suatu penggunaan lahan menjadi penggunaan lahan baru yang berbeda dari awal, dalam konteks ini ialah perubahan lahan pertanian ke perumahan. Lahan nonproduktif yang murah dan strategis untuk dibuat perumahan di daerah Kecamatan Sumber Kabupaten Cirebon sangatlah sedikit dibanding dengan lahan yang produktif atau lebih di spesifikan lahan pertanian, karena di daerah Kecamatan Sumber sendiri mayoritas lahan pertanian lebih dominan, tidak dielakan lahan pertanian menjadi sasaran para investor. Lahan pertanian yang mereka anggap strategis untuk dibangun perumahan mereka rubah menjadi perumahan. Petani yang mempunyai lahan pun harus berfikir keras bagaimana cara mereka memutar perekonomian mereka setelah lahan mereka dijual. Disinilah kesejahteraan petani yang punya langsung lahan pertaniannya dan penggarap lahan pertanian saja yang menjadi titik fokus. Metode yang digunakan disini ialah kualitatif dengan menggunakan sistem observasi, wawancara dan dokumentasi.
\end{abstract}

Kata Kunci : Ekonomi Islam, Alih Fungsi Lahan, dan Kesejahteraan Petani. 


\section{PENDAHULUAN}

Pada mulanya upaya pembangunan $\mathrm{NSB}^{1}$ di identikkan dengan upaya meningkatkan pendapatan per kapita atau populer disebut strategi pertumbuhan ekonomi. Semula banyak yang beranggapan bahwa hal yang membedakan antara negara maju dengan NSB adalah pendapatan rakyatnya. Dengan di tingkatkannya pendapatan per kapita, di harapkan masalah-masalah tentang pengangguran, kemiskinan dan ketimpangan distribusi pendapatan yang dihadapi NSB dapat terpecahkan, misalkan melalui apa yang dikenal dengan "dampak merembes kebawah" (trickele down effect). Indikator berhasil tidaknya pembangunan sematamata dilihat dari meningkatnya pendapatan nasional (GNP) per kapita riil, dalam arti tingkat pertumbuhan pendapatan nasional dalam harga konstan (setelah dideflasi dengan indeks harga) harus lebih tinggi dibanding tingkat pertumbuhan penduduk. ${ }^{2}$

Di negara berkembang seperti Indonesia sendiri rata-rata pendapatan masyarakatnya berada di menengah kebawah, banyak sekali hal yang harus diperbaiki demi kesejahteraan masyarakat secara global di Indonesia, bukan lantas yang kaya semakin kaya sedangkan yang miskin semakin miskin. Pertumbuhan yang meratalah yang diinginkan oleh semua pihak.

Pertumbuhan merata disini ialah pertumbuhan ekonomi yang seimbang dari semua sektor, jangan lantas satu sektor sebagai sebuah kebanggaan yang mana sektor tersebut selalu di eksplorisasi guna pemasukan yang maksimal kenegara yang besar. Memang bagus jika ada satu sektor

\footnotetext{
${ }^{1}$ Ada banyak sebutan untuk NSB (underdeveloped countries), seperti negara kurang berkembang (less developing countries), negara miskin (poor countries). Negara sedang berkembang (developing countries), dan khusus di forum internasional disebut negara Dunia Ketiga (Third World Countries). Mengenai kajian kritis mengenai istilah-istilah pembangunan. Lihat Mudrajad Kuncoro, Ekonomika Pembangunan (Jakarta: Erlangga, 2010), 15.

${ }^{2}$ Mudrajad
Pembangunan, 4.
}

yang merupakan kebanggaan dari sebuah negara, akan tetapi jangan melupakan sektor lain yang membutuhkan bantuan kontrol dari pemerintah.

Asas pertanian adalah tanah. Sedang tenaga manusia, skill dan alat hanya merupakan sarana bukan asas pertanian. Benar, bahwa tenaga manusia mempunyai pengaruh dalam menentukan jenis produksi dan dalam meningkatkan produksi, tetapi bukan asas pertanian. ${ }^{3}$

Istilah tanah di beri arti khusus didalam ilmu ekonomi. Ia tidak hanya bermakna tanah saja seperti yang terpakai dalam pembicaraan sehari-hari, melainkan bermakna segala sumber daya alam, seperti air dan udara, pohon dan binatang, dan segala sesuatu yang diatas dan di bawah permukaan tanah, yang menghasilkan pendapatan dan menghasilkan produk. ${ }^{4}$

Banyak faktor yang menunjang untuk kemajuan negara Indonesia, dimana dari sektor pertanian yang sekarang beralih ke sektor industri. Sebenarnya beralihnya fokus pemerintah sangatlah bagus untuk mempercepat kemajuan negara Indonesia, karena keberalihan fokus tersebut sangat memberi efek besar dalam pembangunan negara tetapi disisi lain sektor pertanian yang sekarang kurang diperhatikan.

Sebenarnya besar harapan negara kita menjadi negara pengekspor beras karena kalau kita lihat dari posisi wilayah sendiri negara Indonesia merupakan negara agraris yang mana masyarakat mayoritas tinggal dipedesaan, diposisi pedesaan itulah sektor pertanian subur makmur dan berkembang maju. Dan jika kita melihat makanan pokok yang dimakan oleh rakyat Indonesia adalah beras maka sangat perihatin jika kita kekurangan akan permintaan beras dan meminta besar ke negara lain, walaupun sekarang akan tersedianya beras di Indonesia di atur oleh Bulogtetapi beras

${ }^{3}$ Abdurrahman al-Maliki, Politik Ekonomi Islam, terj. Ibnu Sholah (Jawa Timur: Al-Izzah, 2001), 45.

${ }^{4}$ Muhammad Sharif Chaundhry, Sistem Ekonomi Islam (Jakarta: Kencana Prenada Media Group, 2012), 161. 
yang dihasilkan oleh Bulog jika kita melihat fakta dilapangan yang diterima oleh rakyat sangatlah jauh dari standar yang layak untuk dikonsumsi dan pembagian beras yang dilakukan di masing-masing daerah sangatlah berbeda, didaerah yang lebih maju beras yang diberikan lebih bagus dibanding dengan daerah yang dibawahnya, tetapi saya tidak membahas lebih lebar akan hal tersebut.

Pada sistem negara Indonesia sekarang suatu daerah diberi kekuasaan untuk mengatur daerahnya sendiri, mengatur roda ekonomi sendiri untuk lebih baik, mengatur penataan ruang didaerah sendiri yang sering disebut dengan otonomi daerah, Cirebon adalah daerah yang posisi wilayahnya sangat bagus, karena dekat dengan laut dan juga pegunungan dan banyaknya pedesaan didalamnya.

Ekonomi pembangunan pedesaan adalah ekonomi pembangunan yang diterapkan untuk kasus perdesaan dalam rangka mencapai perbaikan standar hidup masyarakat pedesaan.penekanan pembahasan identik dengan ilmu ekonomi pembanguna, yakni memperhatikan pertumbuhan ekonomi yang terkait erat dengan aspek sosial, politik dan kelembagaan dengan segala mekanisme segala pencapaiannya yang menjadi pembahasannya tentang potensi pertumbuhan ekonomi bebasis SDA, SDM dan modal sosial, kondisi sosial ekonomi masyarakat pedesaan, kebutuhan infrastruktur pertanian dan fasilitas publik lainnya sesuai karekteristik pedesaannya. ${ }^{5}$

Kecamatan Sumber Kabupaten Cirebon merupakan daerah yang mana sedang merangkak maju perekonomiannya, dengan tataruang yang diciptakan bahwa Kecamatan Sumber merupakan Ibu Kota bagi Kabupaten Cirebon membuat pembangunan sarana dan prasarana semakin cepat terbangun, disinilah membuat daya tarik para Investor untuk meramaikan

\footnotetext{
${ }^{5}$ Atih Rohaeti Dariah, Ekonomi Pembangunan Perdesaan dan Ekonomi Agribisnis (Bandung: CV Kalam Media, 2013), 2.
}

perputaran perekonomian disini. Masyarakat sendiri dari tahun ke tahun terus bertambah, kebutuhan akan tempat tinggal semakin bertambah pula, para investorpun melihat hal tersebut tidak tinggal diam karena ratarata penduduk daerah Kecamatan Sumber mayoritas menengah kebawah maka bukan hal mustahil jika investor membuat perumahan dengan harga yang terjanngkau bisa habis terjual dengan cepat apalagi didukung dengan tataruang pemerintahan untuk Kecamatan Sumber, akan tetapi terjadi problem disaat permintaan akan tempat tinggal yang tinggi tidak berbanding lurus dengan lahan yang tersedia, karena mayoritas lahan yang tersedia merupakan lahan yang produktif, lahan yang digarap oleh masyarakat setempat dan memang kebanyakan dari lahan produktif tersebut ditanamin padi.

Tidak dielakan dengan permintaan masyarakat akan rumah meningkat maka yang terjadi banyak lahan pertanian yang di alih fungsikan menjadi perumahan. disinilah menjadi titik fokus penelitiannya, bagaimana ekonomi islam memandang fenomena tersebut dan para petani yang memiliki lahan pertanian atau mereka penggarap lahan pertanian setelah lahan mereka dijual maka kesejahteraan ekonomi mereka dipertaruhkan, akankah kesejahteraan mereka lebih baik ataukah akan lebih buruk setelah lahan yang mereka punya dijual.

Berdasarkan urain di atas, dapat dirumuskan beberapa masalah, yaitu pertama, bagaimana proses alih fungsi lahan dari pertanian ke perumahan? Bagaimana dampak alih fungsi lahan pertanian terhadap kesejahteraan ekonomi petani setelah lahan tersebut di jual? Bagaimana proses alih fungsi lahan dari pertanian ke perumahan dan dampaknya terhadap kesejahteraan ekonomi petani dalam perspektif ekonomi Islam? 


\section{LANDASAN TEORI}

Konversi lahan adalah perubahan fungsi sebagian atau seluruh kawasan lahan dari semula (seperti yang direncanakan) menjadi fungsi lain. Yang menjadi dampak negatif (masalah) terhadap lingkungan dan potensi lahan itu sendiri. ${ }^{6}$ Konversi lahan atau alih fungsi lahan menurut definisi diatas yaitu lahan yang mana semula merupakan lahan pertanian beralih fungsi menjadi fungsi lain diluar sektor petanian dan berdampak negatif kepada potensi lahan menjadi tidak produktif.

\section{Alih Fungsi Lahan Menurut Perspektif Ekonomi Islam}

Menurut Islam, seseorang dapat memiliki tanah karena beberapa sebab tertentu, secara konvensional seseorang dapat memiliki tanahnya dengan cara membeli tanah tersebut, karena mendapatkan warisan berupa tanah atau memperoleh hibah/hadiah berupa tanah. Selain dari sebab-sebab konvensional tersebut, seseorang juga dapat mendapatkan tanah karena sebab-sebab yang khas yang hanya ada dalam sistem islam, yaitu al-iqtha' (pemberian dari khalifah) dan ihya al-mawat (mengelola tanah terlantar). ${ }^{7}$

\section{Faktor dan Penyebab Terjadinya Alih Fungsi Lahan}

Proses alih fungsi lahan sendiri terdiri secara langsung dan tidak langsung, hal tersebut ditentukan oleh dua faktor, yaitu sistem kelembagaan yang dikembangkan oleh masyarakat dan pemerintah dan sistem non-kelembagaan yang berkembang secara alamiah dalam masyarakat.

Sistem kelembagaan yang dikembangkan oleh masyarakat dan pemerintah antara lain direpresentasikan dalam bentuk terbitnya beberapa peraturan

\footnotetext{
${ }^{6}$ Uchyani Rhina, "Tren Alih Fungsi Lahan Pertanian Di Kabupaten Klanten", Jurnal Sepa, Vol. 8, No. 2 (Juni, 2012): 53.

${ }^{7}$ Hendi Suhendi, Fiqh Muamalah (Jakarta: PT Raja Grafindo Persada, 2005), 268-269.
}

mengenai konversi lahan. ${ }^{8}$ Pemerintah dan masyarakat harus bisa saling memantau, dua faktor inilah yang menyebabkan alih fungsi lahan dapat bisa dilakukan, jangan mementingkan kepentingan pribadi dan menyebabkan kerusakan di masa yang akan datang, kesadaran dari semua pihaklah yang dapat menekan alih fungsi lahan terus berlangsung.

\section{Peraturan Mengenai Alih Fungsi Lahan}

Perumahan dan permukiman sendiri merupakan salah satu kebutuhan pokok manusia. Sebagaimana diamanatkan dalam Undang-Undang dasar (UUD) 1945 dan Pasal 28 UUD 1945, bahwa rumah adalah salah satu hak dasar rakyat dan oleh karena itu setiap Warga Negara berhak untuk bertempat tinggal dan mendapat lingkungan hidup yang baik dan sehat. Selain itu rumah juga merupakan kebutuhan dasar manusia dalam meningkatkan harkat, martabat, mutu kehidupan dan penghidupan, serta sebagai pencerminan diri pribadi dalam upaya peningkatan taraf hidup, serta pembentukan watak, karakter dan kepribadian bangsa.

\section{Definisi Kesejahteraan}

Kesejahteraan adalah kegiatan yang terorganisasi dengan tujuan meningkatkan kesejahteraan dari segi sosial melalui pemberian bantuan kepada orang untuk memenuhi kebutuhan-kebutuhan didalam beberapa bidang seperti kehidupan keluarga dan anak, kesehatan, penyesuaian sosial, waktu senggang, standar-standar kehidupan dan hubungan-hubungan sosial. ${ }^{9}$

\section{Klasifikasi Kesejahteraan Petani}

Luas lahan yang dimiliki petani merupakan simbol derajat sosial-ekonomi seseorang di komunitas desanya. Petani yang tidak

\footnotetext{
${ }^{8}$ Nasoetion L. dan J. Winoto, Masalah Alih Fungsi Lahan Pertanian dan Dampaknya terhadap Keberlangsungan Swasembada Pangan (Bogor: Pusat Penelitian Sosial Ekonomi Pertanian dengan Ford Foundation, 1996), 64.

${ }^{9} \mathrm{~T}$. Sumarnonugroho, Sistem Intervensi Kesejahteraan Sosial, cet. II (Yogyakarta: PT Hanindita, 1987), 28.
} 
memiliki lahan adalah lapisan masyarakat yang paling rendah status sosialnya. ${ }^{10}$ Dengan kata lain kesejahteraan petani disuatu daerah adalah berdasarkan sebarapa luas petani tersebut mempunyai laus lahan yang mereka miliki, jika petani tersebut mempunyai lahan yang luas berarti petani tersebut taraf kesejahteraannya tinggi dan sebaliknya jika petani tersebut tidak mempunyai lahan maka petani tersebut taraf hidupnya rendah.

\section{Kesejahteraan secara Islam}

Dalam pandangan islam masyarakat dikatakan sejahtera bila terpenuhi dua kriteria pertama, terpenuhinya kebutuhan pokok setiap individu rakyat; baik pangan, sandang, papan, pendidikan maupun kesehatannya. Dan kedua, terjaga dan terlindunginya agama, harta, jiwa, akal, dan kehormatan manusia. ${ }^{11}$

Prinsip-Prinsip Ekonomi Islam dalam Alih Fungsi Lahan

Prinsip pertama ialah adil, adil sendiri berasal dari bahasa arab yang secara harfiyah berarti sama. Menurut kamus besar bahasa indonesia, adil berarti sama berat, tidak berat sebelah, tidak memihak, berpihak kepada yang benar, berpegang kepada kebenaran dan sepatutnya. Pembahasan adil merupakan salah satu tema yang mendapat perhatian yang serius dari para ulama dan intelektual muslim. Menurut M. Quraish Shihab, perintah menegakan keadilan dalam Al-Quran dengan mengutip tiga kata yakni al-adl, al-qisth, al-mizan. Kata al-adl menunjukan kepada arti "sama" yang memeberikan kesan adanya dua pihak atau lebih, sedangkan kata al-qist menunjukan kepada arti "bagian" (yang wajar dan patut) dan al-mizan menunjukan kepada arti alat untuk menimbang uang berarti pula "keadilan". Ketiganya sekalipun berbeda bentuknya namun memiliki

\footnotetext{
${ }^{10}$ Wiradi G., Menuju Keadilan Agraria: 70 Tahun Gunawan Wiradi (Bandung: AKATIGA, 2002), 161.

${ }^{11} \mathrm{Https} / / /$ hizbut-tahrir.or.id. Diakses pada tanggal 09 Oktober 2016.
}

semangat yang sama yakni perintah kepada manusia untuk berlaku adil. Dalam Q.S Annisa ayat 58 menjelaskan sebagai berikut. $^{12}$

Setelah adil sudah tercipta maka dalam islam mengenal dengan konsep maslahat. Maslahat sendiri secara etimologi berasal dari kata shalah, yang berarti manfaat. Setiap sesuatu yang memberikan manfaat secara langsung atau melalui perantara, dapat disebut maslahat. Menurut para ahli ushul, manfaat (utulity) itu bisa diperoleh melalui dua katagori, yaitu jalbu almashalih upaya untuk menghasilkan maslahat dan dar'u al-mafasid yang berarti menolak bahaya atau kerusakan. ${ }^{13}$

\section{METODOLOGI PENELITIAN}

Pendekatan yang digunakan dalam penelitian ini adalah metode kualitatif. Menurut Lexi J. Moleong menjelaskan bahwa metode kualitatif adalah metode deskriptif kualitatif. Metode tersebut sebagai prosedur penelitian yang menghasilkan data deskriptif berupa kata-kata tertulis atau lisan dari orang-orang dan perilaku yang dapat diamati. Metode ini digunakan karena beberapa pertimbangan, yaitu pertama menyesuaikan metode deskriptif kualitatif lebih mudah apabila berhadapan dengan kenyataan ganda. Dan kedua metode ini menyajikan langsung hakikat hubungan antara peneliti dan informan. ${ }^{14}$

\section{Lokasi Penelitian}

Lokasi penelitian di Kecamatan Sumber Kabupaten Cirebon Provinsi Jawa Barat adalah salah satu daerah di Provinsi Jawa Barat yang sebagian besar penduduknya bermata pencaharian sebagai petani.

\footnotetext{
${ }^{12}$ Tuntutanislam.com. Diakses pada tanggal 09 Oktober 2016.

${ }^{13} \mathrm{https}$ ://feriskal.wordpress.com. Diakses pada tanggal 09 Oktober 2016.

${ }^{14}$ Lexi J Moleong, Metodologi Penelitian Kualitatif (Bandung: PT Remaja Rosdayakarya Offset, 2004), 4.
} 


\section{Fokus Penelitian}

Penelitian ini difokuskan pada pandangan ekonomi islam terhadap alih fungsi lahan pertanian ke perumahan dan dampak alih fungsi lahan pertanian ke perumahan terhadap kesejahteraan ekonomi masyarakat di Kecamatan Sumber.

Fokus penelitian ini dapat diperinci lagi ke dalam indikator, yaitu Faktor penyebab terjadinya alih fungsi lahan pertanian dari sawah menjadi perumahan, yang dilihat dari 2 (dua) sisi, yaitu pertama, pandangan ekonomi islam terhadap alih fungsi lahan pertanian ke perumahan. Dan kedua, dampak yang ditimbulkan pasca peralihan lahan pertanian ke perumahan di Kecamatan Sumber dari sawah ke Perumahan terhadap kesejahteraan ekonomi petani.

\section{Sumber Data}

Menurut Lofland sumber data utama dalam penelitian kualitatif adalah kata-kata dan tindakan. Selebihnya adalah data tambahan seperti dokumen dan lain-lain. Berkaitan pada hal tersebut, pada bagian ini jenis datanya dibagi kedalam kata-kata dan tindakan, sumber data tertulis, foto dan statistik. ${ }^{15}$

Data penelitian ini dapat diperoleh dari berbagai sumber sebagai berikut:

\section{Sumber Data Primer}

Sumber data primer diperoleh secara langsung melalui wawancara dengan informan. Informan dalam penelitian ini dibagi menjadi tiga yaitu informan utama, informan kunci dan informan pendukung.

Pertama, informan Utama yaitu petani yang menjual lahannya ke pengusaha perumahan. Informan utama ini dipilih dengan pertimbangan karena dianggap mengetahui secara mendalam serta merupakan pelaku dari fenomena yang diteliti.

Kedua, Informan Kunci yang dibutuhkan untuk mengecek kebenaran dan membandingkan pernyataan dari subjek

\footnotetext{
${ }^{15}$ Lexi J Moleong, Metodologi Penelitian Kualitatif, 157.
}

penelitian dengan informan kunci. Perbedaan antara informan utama dengan informan kunci yaitu informan utama merupakan pelaku dari fenomena yang diteliti, sedangkan informan kunci merupakan pelaku sekaligus orang yang lebih mengetahui secara detail tentang fenomena yang diteliti. Informan kunci dalam penelitian ini adalah Dinas Pertanian Kabupaten Cirebon, pemerintahan setempat/kepala desa/lurah di Kecamatan Sumber.

Dan ketiga, Informan Pendukung yang dipilih dari orang yang dapat dipercaya dan mengetahui tentang alih fungsi lahan pertanian dari sawah menjadi perumahan terhadap kesejahteraan ekonomi petani, akan tetapi bukan menjadi informan kunci dalam penelitian ini. Hasil wawancara dengan informan pendukung digunakan untuk untuk mendukung pernyataan dari subjek penelitian. Informan pendukung dalam penelitan ini adalah keluarga petani yang menjual lahannya, masyarakat sekitar lahan yang dijual.

\section{Sumber Data Sekunder}

Data dalam penelitian ini selain diperoleh secara langsung melalui wawancara juga diperoleh dari sumber lain yang berupa sumber tertulis dan tidak tertulis, yaitu pertama, Sumber Pustaka Tertulis dan Dokumentasi ini digunakan untuk melengkapi sumber data informasi, sumber data tertulis ini meliputi data monografi Kecamatan Sumber Kabupaten Cirebon, buku-buku yang relevan perihal skripsi yang berjudul Alih Fungsi Lahan Pertanian Keperumahan dalam Perspektif Ekonomi Islam dan Dampaknya Terhadap Kesejahteraan Ekonomi Petani serta dokumen lain yang terkait dengan penelitian.

Kedua, Foto untuk mengambil gambar atau foto untuk mempermudah saat proses observasi dan kegiatan penelitian atau saat wawancara berlangsung.

Ketiga, Teknik Pengumpulan Data. Dalam hal pengumpulan data penulis menggunakan teknik triangulasi atau 
gabungan untuk kombinasi berbagai metode yang dipakai untuk mengkaji fenomena yang saling terkait dari sudut pandang dan perspektif yang berbeda. Triangulasi sendiri meliputi empat hal, yaitu; triangulasi metode yaitu membandingkan informasi atau data dengan cara yang berbeda (wawancara, observasi dan survey), triangulasi antar peneliti yaitu menggunakan lebih dari satu orang dalam pengumpulan dan analisis data, triangulasi sumber data yaitu menggali kebenaran informasi tertentu melalui berbagai metode dan sumber perolehan data, dan triangulasi teori yaitu membandingkan dengan perspektif teori yang relevan untuk menghindari bias individual peneliti atas temuan atau kesimpulan yang dihasilkan. ${ }^{16}$

Dan keempat, Teknik Analisis Data, yaitu analisis data secara kualitatif dan melakukan reduksi data. Hal ini dilakukan dari hasil wawancara dan observasi tentang alih fungsi lahan pertanian di Kecamtan Sumber dari sawah menjadi perumahan terhadap kesejahteraan ekonomi petani karena data yang diperoleh cukup banyak dan bervariasi sehingga perlu dipilih hal-hal pokok yang sesuai dengan fokus penelitian. Data yang telah direduksi memberikan gambaran yang lebih tajam untuk menggambarkan hasil penelitian yang didapatkan dari lapangan berupa alih fungsi lahan pertanian dari sawah menjadi perumahan dan dampak terhadap kondisi sosial ekonomi masyarakat. Setelah direduksi, data tersebut disajikan dalam bentuk deskriptif melalui analisis, yang berisi mengenai uraian seluruh fokus penelitian dari gambaran umum masyarakat Kecamatan Sumber hingga proses terakhir adalah kesimpulan dari hasil penelitian yang diperoleh.

\footnotetext{
${ }^{16} \mathrm{http}: / /$ mudjiarahardjo.com/artikel/270.html?t ask=view. Diakses pada tanggal 25 Oktober 2016.
}

HASIL PENELITIAN

Alih Fungsi Lahan Pertanian Ke
Perumahan di Kecamatan Sumber
Kabupaten Cirebon

Alih fungsi lahan pertanian keperumahan di Kecamatan Sumber memang terdesak dengan bertambahnya jumlah penduduk, faktor tataruang yang dibuat oleh pemerintah setempatpun tidak bisa ditampikkan menjadi faktor utama cepatnya alih fungsi lahan pertanian keperumahan didaerah ini, jika dilihat dari sektor-sektor daerah di Kecamatan Sumber yang lahan pertaniannya dialih fungsikan keperumahan semua berdekatan dengan pusat pemerintahan Kabupaten Cirebon, dari 12 Kelurahan di Kecamatan Sumber ada 9 kelurahan yang lahan pertaniannya dialih fungsikan menjadi perumahan.

Sedangkan dua Desa lahan pertaniannya tidak teralih fungsikan menjadi perumahan, 9 Kelurahan yang lahan pertaniannya dialih fungsikan yaitu Perbutulan, Kemantren, Sendang, Gegunung, Pejambon, Watubelah, Pesalakan, Kaliwadas, Tukmudal. Daerah tersebut merupakan yang berdekatan dengan pusat pemerintahan, memang daerah-daerah tersebut strategis untuk dibangun perumahan seiring harga lahan itu sendiri bisa dibilang cocok jika dikalkulasikan untuk membuat perumahan subsidi, karena mayoritas ekonomi masyarakat menengah kebawah maka harga per unit rumahpun mereka pihak swasta dengan kalkulasi harga lahan, pemasaran, harga jual rumah, maka mereka membuat rumah subsidi untuk memenuhi permintaan yang tinggi dari masyarakat akan tempat tinggal.

"lahan saya memang sudah lama diincar oleh mereka tetapi tetap saya pertahankan untuk tidak menjualnya, tetapi karena ada desakan dari pembeli, masyarakat dan keluarga akhirnya lahan tersebut saya jual dan saya beli lahan lain ditempat lain". 17

${ }^{17}$ Hasil wawancara dengan bapak munarin, petani di Kelurahan Pesalakan Kecamatan Sumber tanggal 30 Juni 2016. 
Lahan tersebut yang tadinya lahan produktif setelah dijual kepada pihak pemilik perumahan yang terjadi lahan tersebut didiamkan sehingga tampak lahan tersebut seiring waktu berjalan menjadi lahan kebun yang tidak diurus, kalau sudah seperti itu maka lahan tersebut menjadi mudah dalam perijinan untuk dibuat perumahan.

\section{Dampak Alih Fungsi Lahan Pertanian Ke Perumahan Terhadap Kesejahteraan Petani}

Sebelum generasi saya memang orang tua saya petani tetapi setelah orang tua saya sudah berumur dan tidak bisa lagi untuk bertani lahan yang kita punyapun disewakan kepada warga sekitar yang ingin menggarap lahan pertanian tersebut, memang orang tua kita tidak sedikit mempunyai anak, akan tetapi anak-anaknya tidak ada yang menuruni orang tua kita sebagai petani, mereka banyak yang bekerja diperusahaanperusahaan, ada yang diluar kota ikut suaminya dan ada juga yang berdagang. Dengan kesibukan anak-anaknya ketika bapaknya meninggal maka tanah pesawahan tersebutpun dijual dengan kesepakatan keluarga, hasil jual lahan tersebut kita bagi berdasarkan ajaran Islam. ${ }^{18}$

Dari hasil wawancara diatas memang bertani merupakan pekerjaan yang turun temurun tetapi dengan keadaan ekonomi yang sekarang yang menuntut semua serba mewah maka bukan tidak mungkin pemikiran anak-anaknya dengan melihat keadaan ekonomi orang tuanya dahulu yang tidak mereka harapkan untuk serba mewah maka mereka tidak mengikuti profesi tani yang sudah menjadi pekerjaan yang turun temurun tersebut, mereka lebih berfikir untuk mencari uang diluar sana tanpa bertani dengan harapan ekonomi mereka lebih baik tanpa mengeluarkan tenaga ekstra seperti bertani. Memang harus punya tenaga ekstra untuk menjadi seorang petani, dari

\footnotetext{
${ }^{18}$ Hasil wawancara dengan Bapak Dui, pemilik lahan di Kelurahan Kaliwadas tanggal 25 Juni 2016.
}

proses awal sampai akhir panen, semua itu sangat memerlukan tenaga ekstra dan mereka harus bisa membaca cuaca yang terjadi pada saat mereka bertani, karena padi sendiri jika kebanyakan air tidak bagus dan kekurangan airpun tidak bagus.

Di luar petani yang hanya menggarap lahan milik orang lain, disini pemilik lahan sendiri yang mengungkapkan bagamana mereka menjual lahan tersebut. "Kami disini ada yang kerja jadi notaris, polisi dan berdagang. Dari hasil jual lahan tersebut kita gunakan berbeda-beda berdasarkan keperluan yang kita butuhkan, tetapi ada juga dari salah satu anak yang membeli kembali lahan pertanian di daerah lain, bukan dia yang bertani tetapi lahan tersebut dia sewakan kepada masyarakat sekitar yang ingin bertani dengan sistem bagi hasil". ${ }^{19}$

Dalam situasi ini memang kelaurga ini bukan petani, mereka hanya menyewakan lahan tersebut kepada masyarakat yang ingin menggarap lahan mereka, disaat mereka membutuhkan tambahan modal atau suntikan dana maka merekapun menjual lahan tersebut dan penggarap pun mau tidak mau untuk mencari lahan lain yang bisa digarap oleh mereka. Disini hasil yang diperoleh penggarap berbeda sekali dengan petani yang memiliki langsung lahannya sendiri, mereka yang hanya menggarap lahan milik orang lain ada kewajiban untuk bagi hasil dari hasil panennya dengan pemilik lahan, berbeda juga dengan penggarap yang menyewa lahan pertaniannya, mereka sudah dibebankan di awal untuk menyewa lahan tersebut tanpa tahu panen mereka akan berhasil atau puso.

\section{Alih Fungsi Lahan dari Pertanian ke Perumahan dan Dampaknya Terhadap Kesejahteraan Ekonomi Petani dalam Perspektif Ekonomi Islam}

Jika dilihat menurut ekonomi Islam maka alih fungsi yang terjadi diperbolehkan selagi alih fungsi lahan tersebut dilakukan secara adil, yang mana antara penjual dan pembeli

\footnotetext{
${ }^{19}$ Hasil wawancara dengan Bapak Dui., tanggal 25 Juni 2016.
} 
saling menguntungkan dan tidak ada yang dirugikan. Keterangan dari bapak dui bahwa lahan yang mereka punyai didaerah kaliwadas telah dijual untuk dibangun perumahan, jual beli tersebut dilakukan secara saling menguntungkan dan tidak ada yang dirugikan dimasing-masing pihak. Hasil dari jual lahanpun dibagi rata kesemua saudara dan lahan yang mereka jualpun di bangun untuk perumahan dan menuntungkan bagi masyarakat yang membutuhkan akan tempat tinggal, maka dengan kata lain alih fungsi lahan yang dilakukan tersebut dilakukan secara adil tanpa ada tindakan sewena-wena dari salah satu pihak serta bermanfaat bagi masyarakat.

Manfaat atau bisa disebut dengan maslahat, karena didalam islam kata manfaat disebut dengan maslahat, setelah lahan tersebut dijual maka pembangunan perumahan oleh pihak swasta haruslah bermanfaat bagi masyarakat, pembangunan perumahan yang didasarkan kepada permintaan tempat tinggal yang tinggi dikalangan masyarakat maka pembangunan perumahan yang dilakukan oleh pihak swasta dirasakan sangat bermanfaat bagi masyarakat. Manfaat secara Islam disini sering disebut dengan maslahat mursalah yang mana manfaat untuk menghindarkan kemudharatan, memang lahan produktif tersebut dialihkan menjadi perumahan tetapi hal tersbut mengandung banyak manfaat dari pada kemudharaannya, petani yang lahannya mereka jualpun bisa membuka usaha baru yang mana tenaga mereka tidak dikuras sebesar ketika mereka bertani, faktor irigasilah menjadi faktor utama petani.

Bertani memang menjadi profesi yang turun menurun, memang masyarakat di lingkungan saya masyoritas sebagai petani, tetapi irigasi didaerah sini kurang mendukung, air sangat berharga ketika musim kemarau. ${ }^{20}$

\footnotetext{
${ }^{20}$ Hasil wawancara dengan Bapak Munarin, petani di Kelurahan Pesalakan Kec.Sumber pada tanggal 30 Juni 2016.
}

Seperti hal ibu jun di kelurahan sendang, setelah lahan tersebut dijualnya ibujun tidak meneruskan untuk membeli lahan ditempat lain, karena faktor usialah akhirnya pilihan yang diambil adalah membagikan hasil jual lahan tersebut anakanaknya untuk menambah modal mereka dan sebagian disimpan olehnya, untuk kehidupan sehari-hari ibu jun mengandalkan dari anak-anaknya. ${ }^{21}$

Kesejahteraan secara islam ialah bukan hanya kesejahteraan dalam hal ekonomi maupun kesehatan atau pendidikan tetapi dalam terjaga dan terlindunginya agama, harta, jiwa, akal, dan kehormatannya.

\section{KESIMPULAN}

Dari uraian di atas, dapat ditarik 3 (tiga) kesimpulan, yaitu pertama, alih fungsi lahan dari pertanian keperumahan di Kecamatan Sumber Kabupaten Cirebon ada 3 (tiga) yaitu lahan pertanian yang didiamkan terlebih dahulu sehingga seperti lahan yang tidak diurus, lahan pertanian ditanam pohon terlebih dahulu sehingga sudah tidak nampak menjadi lahan sawah dan lahan pertanian yang berada diantara kebun-kebun sehingga disamakan menjadi lahan kebun semua. Dan alih fungsi lahan sendiri terjadi pada wilayah sekitar pusat pemerintahan Kabupaten Cirebon.

Kedua, dampak alih fungsi lahan terhadap kesejahteraan petani di Kecamatan Sumber Kabupaten Cirebon sendiri dari hasil jual lahan tersebut dibagi 3 (tiga), yaitu petani asli maka akan kebingungan untuk bekerja disektor lain dan pada akhirnya menunggu pemasukan dari anak dan keluarga disamping mereka membuat usaha kecil-kecilan, penyewa lahan sendiri mereka akan untung dan mendapatkan tambahan modal, penggarap lahan tanpa mempunyai lahan sendiri maka mereka yang mampu fisiknya akan mencari lahan lain untuk mereka garap dan jika tenaga mereka sudah

\footnotetext{
${ }^{21}$ Hasil wawancara dengan Ibu Junaeni, petani di Kelurahan Sendang Kecamatan Sumber tanggal 24 Juni 2016.
} 
tidak mampu untuk bertani maka mereka akan berhenti dan menunggu pemasukan dari anak dan keluarga mereka untuk bertahan hidup. Karena kendala utama ada pada keturunan petani yang enggan lagi untuk bertani.

Dan ketiga, dalam perspektif ekonomi Islam alih fungsi lahan boleh dilakukan di Kecamatan Sumber Kabupaten Cirebon karena tidak bertentangan dengan prinsip adil dan maslahat dan dampak alih fungsi lahan dari pertanian keperumahan menurut perspektif ekonomi Islam melalui prinsip kesejahteraan maka petani tersebut dikatakan sejahtera.

\section{DAFTAR PUSTAKA}

Al-Maliki, Abdurrahman. Politik Ekonomi Islam, terj. Ibnu Sholah. Jawa timur: Al-Izzah 2001.

Chaundhry, muhammad Sharif. Sistem Ekonomi Islam. Jakarta: Kencana Prenada Media Group, 2012.

Dariah, Atih Rohaeti. Ekonomi Pembangunan Perdesaan dan Ekonomi Agribisnis. Bandung: CV Kalam Media, 2013.

G., Wiradi. Menuju Keadilan Agraria: 70 Tahun Gunawan Wiradi. Bandung: AKATIGA, 2002 .

http://mudjiarahardjo.com/artikel/270.html?t ask=view

https://feriskal.wordpress.com.

Https://hizbut-tahrir.or.id.

Kuncoro, Mudrajad Kuncoro. Ekonomika Pembangunan. Jakarta: Erlangga, 2010.

L, Nasoetion, dan J. Winoto. Masalah Alih Fungsi Lahan Pertanian dan Dampaknya terhadap Keberlangsungan Swasembada Pangan. Bogor: Pusat Penelitian Sosial Ekonomi Pertanian dengan Ford Foundation, 1996.

Moleong, Lexi J. Metodologi Penelitian Kualitatif. Bandung: PT Remaja Posdayakarya Offset, Bandung, 2004.

Rhina, Uchyani. "Tren Alih Fungsi Lahan Pertanian Di Kabupaten Klanten".
Jurnal Sepa, Vol. 8, No. 2 (Juni, 2012).

Suhendi, Hendi. Fiqh Muamalah. Jakarta: PT Raja Grafindo Persada, 2005.

Sukirno, Sadono. Ekonomi Pembangunan: Proses, Masalah, dan Dasar Kebijakan. Jakarta: Kencana, 2007.

Sumarnonugroho, T. Sistem Intervensi Kesejahteraan Sosial, cet. II. Yogyakarta: PT Hanindita, 1987. 